\title{
Comments
}

\section{TAX ELECTION CORPORATIONS: SUBCHAPTER S OF THE INTERNAL REVENUE CODE OF 1954}

\begin{abstract}
Section 64 of the Technical Amendments Act of 1958 (72 Stat. 1650) amends the Internal Revenue Code of 1954 by adding at the end of chapter 1 a new subchapter $S$, comprising sections 1371 through 1377 , and by adding a new section 6037 , relating to information returns. Subchapter S permits a "small business corporation" . . to elect ... not to be subject to the income tax imposed by chapter 1 . The election may be made only if the corporation is a domestic corporation; is not a member of an affiliated group of corporations ... ; and does not have (1) more than one class of stock, (2) more than 10 shareholders, (3) a shareholder (other than an estate) who is not an individual, or (4) a shareholder who is a nonresident alien. An election ... may be made only with respect to a taxable year beginning after Deceniber 31,1957 , and ending after September 2, 1958. The election shall be effective for the taxable year of the corporation for which it is made and for all succeeding taxable years unless it is terminated. . . The taxable income of an electing small business corporation, to the extent that it exceeds dividends distributed in moncy out of earnings and profits of the taxable year, is taxed directly to the shareholders to the extent that it would have constituted a dividend if it had been distributed on the last day of the corporation's taxable year. 1
\end{abstract}

The complexities and interrelations of this legislation are such that a discussion and analysis could take any number of approaches. In the interest of clarity, however, the present comment will discuss the provisions of the legislation in the order in which they appear in the Internal Revenue Code. ${ }^{2}$

\section{Section 1371: Qualifications}

Section 1371 defines a "small business corporation," which is the name given to those corporations which, initially, are quahified to take advantage of the new legislation. The requirements for being a small business corporation are: (1) the corporation must be a domestic corporation; (2) it must not be a member of an affiliated group within the meaning of section 1504 ; (3) it must have no more than 10 shareholders; (4) it must not have as a shareholder a person, other than an estate, who is not an individual; (5) it unust not have a shareholder who is a nonresident ahien; and (6) it must have only one class of stock.

The requirements that a small business corporation must be a domestic corporation, must not be a member of an affiliated group and must not have as a

1 Temp. Treas. Reg. § 18.1-1(a), 23 Fed. Reg. 7484 (1958).

2 This legislation has been the subject of extensive comnient. See, e.g., CCH, TAX-OPtION CoRporations (1958); Anthoine, Federal Tax Legislation of 1958: The Corporate Election and Collapsible Amendment, 58 ColuMr. L. REv. 1146 (1958); Axelrad, Recent Developments in Collapsible Corporations, 36 TAxEs 893, 906 (1958); Crane, Election of Certain Small Business Corporations as to Income Tax Status, 10 Hastings L.J. 271 (1959); Meyer, Subchapter S Corporations, 36 TAxes 919 (1958); Price, The Small Business Tax Revision of 1958, 14 Bus. LAw. 329 (1959); Note, Optional Taxation of Closely Held Corporations Under the Technical Amendments Act of 1958,72 HARV. L. REV. 710 (1959).

3 It should be noted at the outset that "small business corporation" is a misnomer, since the only respect in which qualifying corporations need be small is the limitation on the number of sbareholders. But see text at note 69 infra.

4 For the purpose of this requirement, domestic corporations apparently include associations, joint-stock companies and insurance companies, which are treated as corporations for tax purposes. See $\$ 7701$ (a) (3). (Unless otherwise specified, all references in this comment to sections refer to the Internal Revenue Code of 1954, as amended by the Technical Amendments Act of 1958, 72 Stat. 1650.) 
shareholder a nonresident alien will receive no further comment. However, the other three requirements present more difficult questions of interpretation and will therefore be examined in some detail.

The question arises whether shares of stock owned jointly by more than one person are to be treated as owned by only one person or by the number of coowners, particularly if the shares are registered in the name of only one co-owner. The Internal Revenue Service has taken the position that if stock is owned by tenants by the entirety, tenants in common, joint tenants or by husband and wife as community property, each co-owner shall be deemed to be a separate shareholder for the purpose of section 1371(a)(1). ${ }^{5}$ The Service likewise takes the position that when stock is owned by two or more minors but held in the name of a guardian or custodian, each minor is counted as a shareholder. ${ }^{6}$ Under the reasoning of this ruling, in any form of joint or representative ownership the number of shareholders will be determined by the number of persons holding a beneficial interest in the shares.

The requirement that each shareholder must be an individual, with the exception of an estate, results in the obvious disqualification of a corporation with corporate shareholders. However, some of the other disqualifications are not so obvious. It appears that partnerships, associations, and trusts, both inter vivos and testamentary, are not individuals for the purposes of section 1371(a)(2). The exception in favor of an estate means that stock held by the executor or administrator of a decedent's estate shall not cause a corporation to be disqualified as a small business corporation. For these purposes it is apparently immaterial that the executor or administrator is itself a corporation or other form of organization whose direct ownership of shares would result in disqualification. The Service has also indicated that stock held for minors by a guardian shall be deemed to be held directly by the minors for this purpose, and also that stock transferred to a minor under the Uniform Gifts to Minors Act or Gifts of Securities to Minors Act is not owned by a trust and hence does not disqualify the corporation under section $1371(a)(2) .^{8}$

This leaves unanswered the consequences of other forms of representative ownership of stock, such as voting trustees and receivers, assiguees for creditors, and trustees in bankruptcy. The argument has been made that none of these forms of ownership would result in a disqualification, ${ }^{9}$ but it could be argued with equal force that these forms of ownership are essentially similar to an ordinary trust, which is disqualified. At any rate, these representative forms of ownership should be employed with caution.

5 Technical Information Release 113 (Nov. 26, 1958).

I Ibid.

T Section 7701(a)(1) provides that an individual is a person other than a trust, cstate, partnership, association, company or corporation. Of course, a special exception is made for estates. The position that all these forms, other than an estate, are not individuals within the meaning of $\S 1371$ (a) (2) is supported in part by both the Senate Committee report and the Service. S. REP. No. 1983, 85th Cong., 2d Sess. 88 (1958); Technical Information Release 113 (Nov. 26, 1958).

Note, however, the possibility that the grantor of a Clifford trust, to whom the income is taxed under $\$ 671$, may be treated as the shareholder for this purpose and would therefore qualify if he himself were an individual. See Anthoine, Federal Tax Legislation of 1958: Tho Corporate Election and Collapsible Amendment, 58 Cosus. I. REv. 1146, 1151 (1958); Note, 72 HARv. L. REv. 710, 711 (1959).

8 Technical Information Release 113 (Nov. 26, 1958).

o CCH, TAX-Option Corporamions III 94-95 (1958). 
The Service has taken the position that a corporation with class $A$ voting common and class $B$ nonvoting common stock outstanding has more than one class of stock and is thus disqualified under section 1371 (a) (4).$^{10}$ Conversely, however, two series of stock with the same voting, dividend and liquidation rights will be treated as one class of stock. Furthermore, a corporation with two classes of stock authorized will not be disqualified so long as only one such class is issued and outstanding. ${ }^{11}$ This analysis leaves unsettled the status of treasury shares of a class different from that of issued and outstanding shares. Perhaps the safe course would be to retire any such treasury shares.

There is nothing in the statute to indicate that debt securities are treated as "stock" for purposes of the requirement that the small business corporation may not have more than one class of stock, but the more closely such bonds resemble preferred stock the more likely it is that the bondholders may be deemed to be stockholders. ${ }^{12}$ In this connection it should be noted that if securities which are in form debt are treated as equity for the purpose of determining the number of classes of stock outstanding, it is likely that such securities will also be treated as stock for purposes of determining the number of shareholders under section 1371 (a) (1).

Section 1371(b) provides that for the purposes of subchapter $S$, the term "electing small business corporation" means a small business corporation which has made an election under section 1372(a) which is in effect for the taxable year in question.

\section{Section 1372: Election and Termination}

Section 1372 (a) provides that any small business corporation may elect not to be subject to the taxes normally imposed upon a corporation. If such an election is made and in effect, the income of the corporation will be taxed directly to the shareholders in a manner similar to the treatment of members of a partnership. It should be emphasized at this point, however, that the tax treatment of an electing small business corporation differs in several material respects from that of a partnership. ${ }^{13}$

The election will be valid only if consented to by all persons who are shareholders on the first day of the first taxable year for which such election is effective or on the day on which the election is made, whichever is later. An election is effective for the taxable year of the corporation for which it is initially made and for all succeeding taxable years unless it is terminated or revoked in accordance with section $1372(\mathrm{e})$.

An election may be made by a small business corporation for any taxable year —beginning after December 31, 1957 and ending after September 2, 1958-at any time during the first month of such taxable year or at any time during the prior

10 Technical Information Release 113 (Nov. 26, 1958).

11 Ibid.

12 The corporation laws of some states permit bondholders to have voting and other rights which are usually the indicia of equity, rather than debt, securities. E.g., CAI. CORP. CoDE $\S 306$.

The impact of the doctrine of "thin capitalization" should be considered. When a corporan tion is deemed to be inadequately capitalized because of the debt-equity ratio, the alleged debt is treated as stock for some purposes. This raises the question of whether this "stock" will be deemed to be stock of the same class of the true shares outstanding. Such constructive stock more probably would be regarded as in the nature of preferred stock, thereby causing a disqualification.

13 See, e.g., notes 44, 48-50, 62, 67 infra and accompanying textual discussions. 
month. ${ }^{14}$ Temporary regulations have provided for the manner in which such an election must be made. ${ }^{15}$

Section 1372 (e) provides one way in which an election may be revoked and four ways in which it may be terminated:

(1) An election shall terminate if any person who was not a shareholder in the small business corporation on the first day of the first taxable year of the corporation for which the election was effective or on the day on which the election was made, whichever is later, becomes a shareholder and does not consent to such election within thirty days after becoming a shareholder. The form and manner of filing such consent is provided by temporary regulations. ${ }^{16}$ It should be noted that under this provision the election is terminated if the new shareholder merely fails to consent; active opposition on his part is not required.

(2) An election inay be revoked by a small business corporation for any taxable year after the first taxable year of the corporation for which the election was effective. ${ }^{17}$ If the revocation is made before the close of the first month of a taxable year ${ }^{18}$ it shall be effective for that year; otherwise it shall be effective only for all succeeding taxable years. For a revocation to be effective it must be made with the consent of all persons who are shareholders at the time.

(3) An election shall terminate if at any time after the first day of the first taxable year of the corporation for which the election was effective or after the day on which the election was made, whichever is later, the corporation ceases to be a small business corporation under section 1371 (a).

(4) An election shall terminate if for any taxable year for which an election is in effect the corporation derives more than eighty per cent of its gross receipts from sources outside the United States. ${ }^{19}$

(5) An election shall terminate if for any taxable year of the corporation for which an election is in effect more than twenty per cent of the corporation's gross receipts are derived from royalties, rents, dividends, interest, annuities, and sales or exchanges of stock or securities. ${ }^{20}$

It is to be noted that under the methods of termination described in paragraphs (1), (3), (4) and (5), the termination is effective for the taxable year in which the disabling events take place and for all succeeding taxable years of the corporation.

14 Any discussion of the availability of the election for taxable years beginning before September 2, 1958 and ending after such date is omitted since the time for filing an election for such period has expired ( $\$ 1371$ (c) (2)).

15 Temp. Treas. Reg. $\S 18.1-1$ (b), 23 Fed. Reg. 7484 (1958).

$16 I d$. $\$ 18.1-1$ (c), 23 Fed. Reg. 7484.

17 Note that a termination under the other four methods is effective immediately, whereas a revocation under this method cannot be effective for the first year during which the election was originally effective.

18 See text following note 20 infra.

19 Puerto Rico is not part of the United States for this purpose.

20 Gross receipts from sales or exchanges of securities are taken into account only to the extent of gains therefrom ( $\$ 1372(\mathrm{e})(5))$.

The types of proscribed income are the same as those which may make a corporation a personal holding company under $\$ 543$. However, it should be understood that under this method of termination the corporation need not be a personal holding company in order for a termination to be caused.

The term "rent" does not include fees received for the use of rooms in hotels and motels. Technical Information Release 113 (Nov. 26, 1958). However, the term "interest" does include interest income of a bank or licensed personal finance company, even though such interest income is exempted from the personal holding company provisions of $\S 543$. Ibid. 
On the other hand, a revocation under paragraph(2) is not effective for the current taxable year unless made before the close of the first month thereof, and in no case is it effective for the first taxable year for which the corporation was an electing corporation. This distinction was probably motivated by a desire to prevent tax avoidance by using the hindsight of several months operations before deciding whether to revoke an election. Whether this desire was in fact accomplished is doubtful since a corporation strongly desirous of terminating its status as an electing corporation could easily arrange to have some transaction take place which would cause its election to be terminated under one of the other provisions. Furthermore, the necessity for the provision is doubtful in view of the penalties imposed upon the shareholders of a corporation whose election is terminated or revoked. ${ }^{21}$

Section $1372(f)$ provides that if the election of a small business corporation is terminated or revoked under any of the provisions of section $1372(\mathrm{e})$, the corporation and any successor corporation shall not be eligible to make another election for five years unless the Secretary or his delegate consent to a new election. This provision was designed to prevent corporations froin going on or off the electing status from time to time as tax consequences of an election changed. ${ }^{22}$ It can therefore be anticipated that the Commissioner will permit new elections to be made within the five year period if tax avoidance was not the motivating factor in the termination or revocation.

This penalty provision merely highlights the drafting problems presented by the methods in which an election may be terminated or revoked. In particular, care must be taken to ensure that the corporation will continue to be a small business corporation and that no shares can be transferred to a person who will not consent to the election or who is not an "individual," assuming, of course, that the corporation and its shareholders wish to maintain the status of electing corporation. A suggested restriction on transfer is a provision that shares can be transferred only to the corporation at book value or to a qualified person who binds himself in advance to consent to the election.

\section{Section 1373: Constructive Dividends}

Section 1373 provides the method in which the incoine of the electing corporation is taxed to the shareholders. Section 1373 (a) states the general rule to be that the "undistributed taxable income" of the electing corporation for any taxable year shall be included in the gross income of the shareholders of the election corporation.

"Undistributed taxable incoine" is determined by first calculating the taxable income of the corporation-just as if it were a tax-paying entity-but without deduction for net operating loss ${ }^{23}$ or the deductions of sections 242 through 247.24

21 See text at notes 22 and 57 infra.

22 S. REp. No. 1983, 85th Cong., 2d Sess. 88 (1958). For two reasons why this "penalty" provision may prove to be msignificant, see text at note 57 and note 70 infra.

23 The effect of this provision is that an electing corporation loses the benefits of a net operating loss carryover from preceding years. It is not certain, however, whether a corporation which elects can use its prior loss carryover if the election is later terminated or revoked within the five year carryover period. See Note, 72 HARv. L. REv. 710, 715 (1959). A corporation with such a carryover, or one anticipating a large net operating loss which its shareholders would not be able to utilize, may not wish to become an electing corporation.

24 These sections deal with partially tax-exempt interest and intercorporate dividends. The disallowance of the intercorporate dividend deduction may be serious if the corporation is a so-called "dividend shelter corporation." See CCH, TAX-Option Corporations $\pi 76$ (1958). For discussion of the consequences of disallowance of the deduction for partially tax-exempt interest, see note 29 and text at notes 49 and 62 infra. 
Distributions of money, but not of other property, during the taxable year out of current earnings and profits are then deducted to arrive at "undistributed taxable income." The shareholders include in their gross income the amount they would have received as taxable dividends under section 316(a) had "undistributed taxable income" been distributed pro rata to them on the last day of the corporation's taxable year. ${ }^{25}$ The amount so attributed to the shareholders of an electing small business corporation shall hereafter be referred to as "constructive dividends."

Each person who is a shareholder of an electing corporation on the last day of the taxable year in question must include in his gross income for his taxable year in which or with which the taxable year of the corporation ends ${ }^{26}$ the amount he would have received as a dividend if on such last day there had been distributed pro rata to the shareholders an amount equal to the undistributed taxable income of the corporation for the year in question. The amount so attributed to the shareholders is treated as having been received on the last day of the taxable year of the corporation, ${ }^{27}$ regardless of whether it is actually received.

Calculation of the amount taxable to the shareholders as constructive dividends may be illustrated by the following examples. ${ }^{28}$ Suppose that an electing corporation with sole shareholder $X$ has no accumulated earnings and profits but has both taxable income and earnings and profits of $\$ 100,000$ for the current taxable year. ${ }^{20}$ If there are no distributions during the year, undistributed taxable income would be $\$ 100,000$ and $X$ would include that sum in his gross income as a constructive dividend. If the electing corporation distributes cash of $\$ 50,000$ during the taxable year the distribution will be taxed as a dividend ${ }^{30}$ of $\$ 50,000$ and since all cash

25 Under $\$ 316(a)$ both accumulated and current earnings and profits are available for dividends.

26 There is no provision in the code requiring the corporation and its shareholders to have the same taxable year, as there is in the case of partnerships in $\S 706$. This may enable deferment of income by incorporating with a different taxable year. See CCH, TAX-Option CorporsTHONS $\llbracket 29$ (1958).

27 This provision may permit shareholders of an electing corporation to shift accrued constructive dividends at any time before the last day of the corporation's taxable year through gifts or sales of stock. The fact that status as an electing corporation may be destroyed in a number of ways, thereby making tenuous the shareholder's "right" to have constructive dividends attributed to him, makes improbable the application of the doctrine of such cases as Helvering v. Horst, 311 U.S. 112 (1940), to this situation. See note 40 infra for the different treatinent of accrued net operating losses.

When the shareholder has a taxable year different from that of the electing corporation and he receives an actual cash distribution allocable to current earnings and profits he is taxable in the year of receipt rather than in the year in which the corporation's taxable year ends. Similarly, a distribution of property is not subject to these special rules and is taxed in the usual manner under $\$ 301$. These factors permit some deferment of income by regulating the time when actual cash distributions are made to shareholders whose taxable years do not coincide with that of the electing corporation.

28 The analysis contained in the examples in the following text was inspired by a similar discussion in Note, Optional Taxation of Closely Held Corporations Under the Technical Anendments Act of 1958, 72 HARv. L. REv. 710, 717-18 (1959).

${ }^{29}$ Taxable income cannot exceed current earnings and profits because of the special pro. visions of $\$ 1377$ (b) (discussed in text at note 62 infra). It can, however, be less than current earnings and profits if the corporation has some items of income which are tax-exempt at the corporate level but which do not carry over that status to the shareholders, e.g., tax-exempt interest income. See note 24 supra and text at notes 49 and 62 inffra.

30 The dividend credit, exclusion and retirement imcone credit provisions of the code will not be applicable to these dividends because of the special provisions of $\S 1375(\mathrm{~b})$. See text at note 52 infra. 
distributions out of current earnings and profits are deducted from taxable income in computing undistributed taxable income, $X$ will be further taxable on $\$ 50,000$, the full amount of the remaining undistributed taxable income, as a constructive dividend.

If, instead of money, a distribution of property with a basis and fair inarket value of $\$ 50,000$ is made during the current year, undistributed taxable income would still be $\$ 100,000 .{ }^{31}$ In determining what part of this undistributed taxable income would have been taxable as a dividend under section $316(\mathrm{a})$ had it been distributed on the last day of the taxable year, however, it is necessary to allocate the current earnings and profits of $\$ 100,000$ between the property distribution and the fictional distribution of undistributed taxable income. The regulations pertaining to corporate distributions in general provide that if there are cash distributions for a year which total more than the current earnings and profits, the current earnings and profits are prorated over all the distributions..$^{32}$ There are no regulations, however, concerned with distributions which include property other than money, the total of which distributions exceed current earnings and profits. If current earnings and profits are charged first with all actual distributions and then with undistributed taxable income, the property distribution would be taxed as a dividend $^{33}$ of $\$ 50,000$, leaving current earnimgs and profits of only $\$ 50,000$. Thus constructive dividends would be limited to $\$ 50,000$, a total taxable distribution of $\$ 100,000$, even though undistributed taxable income is $\$ 100,000$.

If the electing corporation distributes cash of $\$ 25,000$ and property with a basis and fair market value of $\$ 50,000$, a more complex case is presented. If both actual distributions are charged chronologically against current earnings and profits, the entire amount of each distribution will be taxed as a dividend ${ }^{34}$ and the undistributed taxable income will be $\$ 75,000$ - the original $\$ 100,000$ less the $\$ 25,000$ cash distribution. Since only $\$ 25,000$ of current earnings and profits remain at the end of the taxable year, however, only that ainount is taxable as a constructive dividend even though undistributed taxable income is $\$ 75,000$. However, if the annount of current earnings and profits is divided pro rata among all distributions, including the fictional distribution of undistributed taxable income, a determination of the amount of constructive dividends is inpossible since a determination of either the amount of undistributed taxable income or the portion of the inoney distribution which will be allocated to current earnings and profits depends on a prior computation of the other amount. ${ }^{35}$ It therefore seems that in all cases involving electing corporations, current earnings and profits should be diminished first by actual distributions made during the taxable year and then by the fictional distribution of undistributed taxable income at the end of the taxable year. It should be noted,

31 Because undistributed taxable income is not reduced by non-cash distributions. See text following note 24 supra.

32 Treas. Reg. $\$ 1.316-2$ (b) (1955). Of course, these regulations do not specify that fictional distributions shall be treated as cash distributions for purposes of this rule.

33 See note 30 supra.

34 Ibid.

35 This is because undistributed taxable income is reduced by the amount of cash distributions allocable to current earnings and profits, and therefore cannot be determined until the amount of cash distributions so allocated is determined. At the same time, however, the amount of cash distributions which is allocable to current earnings and profits under this pro rata formula depends upon the amount of current earnings and profits absorbed by the fictional distribution of undistributed taxable income and therefore cannot be determined before that amount is determined. 
however, that if there are no accumulated earnings and profits the shareholders can be taxed only on the amount of current earnings and profits regardless of the nethod of allocation employed. Thus the total taxable distribution will be the same under any allocation method. ${ }^{36}$

If the electing corporation has accumulated earnings and profits, however, the method of allocating current earnings and profits becomes significant in determining the total amount taxable to the shareholders. If an electing corporation with accumulated earnings and profits of $\$ 300,000$ and both current earnings and profits and taxable income of $\$ 100,000$ makes a distribution of property with a basis and fair market value of $\$ 75,000$ followed by a cash distribution of $\$ 75,000$, a chronological allocation of current earnings and profits to all actual distributions will mean that only $\$ 25,000$ of the cash distribution is a dividend out of current earnings and profits- $\$ 100,000$ current earnings and profits less $\$ 75,000$ distribution of property. Therefore only $\$ 25,000$ will be deducted from taxable income in arriving at undistributed taxable income-a result of $\$ 75,000$. The net result will be a total taxable distribution of $\$ 225,000$, composed of $\$ 75,000$ constructive dividends and $\$ 50,000$ cash from accumulated earnings and profits, and $\$ 25,000$ cash and $\$ 75,000$ of property from current earnings and profits. Had the cash been distributed before the property, the entire $\$ 75,000$ cash distribution would have been charged against current earnings and profits under the chronological method, leavmg an undistributed taxable income of $\$ 25,000$. The total amount taxable as a dividend would then be $\$ 175,000$, composed of $\$ 25,000$ constructive dividends and $\$ 50,000$ of property from accumulated earnings and profits, and $\$ 75,000$ cash and $\$ 25,000$ of property from current earnings and profits. Thus, in cases in which actual distributions exceed in amount the current earnings and profits of the electing corporation, the amount of constructive dividends attributed to the shareholders depends (1) upon the allocation of current earnings and profits to cash distributions, which in turn depends upon the order of all distributions, and (2) upon the amount by which accumulated earnings and profits exceed the excess of actual distributions over current earnings and profits. ${ }^{37}$ It would seem that the purpose of the statute, however, is to tax the shareholders of an electing corporation (1) on the corporation's current taxable income, whether retained or distributed, and (2) in addition to tax accumulated earnings and profits $(a)$ to the extent of the excess of cash distributions over current earnings and profits and $(b)$ to the extent of all property distributions. ${ }^{38}$ If this premise is correct, current earnings

36 If there are no accumulated earnings and profits neither the actual distributions nor the constructive dividend will be eligible for the dividend credit, exclusion and retirement insome credit provisions. See text at note 52 infra. The allocation method employed will, however, determine the amount of tax burden borne by each distribution.

37 If current earnings and profits have been absorbed by actual distributions, undistributed taxable income must be allocated to accumulated earnings and profits. Since undistributed taxable income is a constructive dividend only to the extent that it would have been a dividend if actually distributed, it can be so treated as a constructive dividend only if there are remaining accumulated earnings and profits. The reason why it is possible to have undistributed taxable income even if there are no current earnings and profits is because undistributed taxable income is reduced only by cash distributions even though a property distribution may have been allocated to current earnings and profits by the allocation method under discussion.

38 This analysis is based on the provisions of $\S 1373$. Section 1373 (c) provides, in effect, that the total current earnings and profits shall be taxed to the sharcholders, whether in the form of actual cash distributions or as constructive dividends. The fact that actual cash distributions reduce undistributed taxable incoine only to the extent allocable to current earnings and profits evidences an intent to tax the excess as a dividend to the extent of accumulated 
and profits should be allocated first to cash distributions, regardless of the order in which actual distributions are made, in order to prevent taxation as a dividend out of accumulated earnings and profits of any part of cash distributions which do not exceed current earnings and profits. Application of this method of allocation to our hypothetical case would cause the second result discussed above-a total taxable distribution of $\$ 175,000 .^{39}$

\section{Section 1374: Net Operating Loss}

Section 1374 provides for allocation of any net operating loss of the electing corporation to its shareholders. Each person who was a shareholder of an electing corporation at any time during a taxable year of the corporation in which it has a net operating loss is allowed as a deduction from gross income, for his taxable year in which or with which the taxable year of the corporation ends, an amount equal to his portion of the electing corporation's net operating loss. A shareholder's portion is determined by dividing the total net operating loss by the number of days in the taxable year of the corporation, thus ascertaining the daily net operating loss, and by then allocating the daily figure pro rata to those persons who were shareholders on each such day. ${ }^{40}$ The total net operating loss of the electing corporation is computed in accordance with section 172 (c), except for the disallowance of the deductions provided for in sections 242 through 247.41

A shareholder's portion of the net operating loss for any taxable year of the electing corporation may not exceed the sum of the adjusted basis of his stock and the adjusted basis of any indebtedness of the corporation to him. Both such adjusted bases are determined without regard to the special adjustments provided for in section 1376 for the current year ${ }^{42}$ and are determined as of the close of the

earnings and profits. Similarly, the fact that property distributions do not reduce undistributed taxable income evidences an intent to tax such distributions as dividends to the extent of accumulated earnings and profits.

39 An alternative method would be to prorate current earnings and profits among all actual distributions and to allocate the balance of actual distributions and undistributed taxable income to accumulated earnings and profits, so as to eliminate the importance of the order of actual distributions. In the above example this would mean that the $\$ 100,000$ of current earnings and profits would be divided equally between the cash and property distributions, leaving undistributed taxable income of $\$ 50,000$ - the original $\$ 100,000$ less the $\$ 50,000$ of the cash distribution which is allocated to current earnings and profits. The total amount taxable as a dividend then would be $\$ 200,000$, composed of $\$ 50,000$ constructive dividends, $\$ 25,000$ cash and $\$ 25,000$ of property from accumulated earnings and profits, and $\$ 50,000$ each of cash and property from current earnings and profits. This method eliminates the significance of the order of actual distributions, but it does not achieve the desired result of preventing taxation as a dividend out of accumulated earnings and profits of any part of cash distributions which do not exceed current earnings and profits.

A further complication is added to the significance of the method of allocation if the fair market value of the property distribution exceeds its basis and the fair market value of all distributions exceeds current earnings and profits.

${ }^{40} \mathrm{Cf}$. note 27 supra, discussing the method of attribution of constructive dividends. This allocation of the electing corporation's net operating loss on a daily basis prevents a person from buying stock with an accrued loss im order to offset personal income.

41 See note 24 supra. Note also that the corporation may not use a net operating loss carryover in determining the current year's net operating loss. See note 23 supra.

42 Section 1376 provides for basis adjustments to reflect retained constructive dividends and the shareholder's portion of net operating loss. See text following note 60 infra. The qualification under discussion means that only the special adjustments for the current year are disregarded in determining adjusted basis for the purpose of ascertaining the shareholder's allowable portion of the electing corporation's net operating loss. 
corporation's taxable year in question. ${ }^{43}$ It should be noted that if any part of the loss is not allowed as a deduction in the year in which it is sustained because it exceeds the sum of these adjusted bases, it cannot be taken as a deduction by the shareholder in any future year. ${ }^{44}$

Section 1374(d) provides that the deduction allowed the shareholders for their portion of an electing corporation's net operating loss shall be considered as a deduction attributable to a trade or business carried on by the shareholder. ${ }^{45} \mathrm{It}$ is also provided that if the shareholder's allowable portion of the loss exceeds his income, he can carry back and forward that excess as if it were his net operating loss froin a trade or business. ${ }^{46}$ However, any such excess may not be carried back to a year prior to 1958; but the amount which may be carried forward is not reduced by any pre-1958 income of the shareholder.

\section{Section 1375: Tax Character of Distributions}

Section 1375(a) provides that the amount included in the income of the shareholders as dividends (including both constructive and actual dividends), to the extent allocable to current earnings and profits, ${ }^{47}$ shall be treated as a long-term

43 Except in the case of a person who is no longer a shareholder on the last day of the corporation's taxable year, in which event the adjusted bases are determined as of the close of the last day on which such person was a shareholder.

44 This fact reduces the attractiveness of being an electing corporation if there is low basis stock, especially if the corporation could have utilized the entire net operating loss as a carryback or carryover if it were not an electing corporation. It may be possible to alleviate this feature by the device of having the shareholders make loans or capital contributions to the corporation before the close of the taxable year, the basis of such loans or contributions increasing the amount of net operating loss allowable to the shareholders. Cf. $\$ \S 704$ (d) and 752, which provide that a borrowing by a partnership increases the basis of the lending partner's share in the firm and enables him to take a deduction for a partnership ioss that otherwise might not be currently deductible. Even if the partner's share is not thus increased in the current year, ho can take the deduction in a later year when his basis is increased ( $\$ 704(d)$ ).

A further limitation on the amount of the corporation's net operating loss which is allowable to the shareholder is imposed by $\$ 270$, which provides that if a taxpayer bas otherwise allowable losses from a trade or business in excess of $\$ 50,030$ for each of five consecutive years, his taxable incone for each of these years shall be recornputed, limiting the net loss in each year to $\$ 50,000$. By providing that the shareholder's portion of the electing corporation's net operating loss shall be treated as a loss incurred in a trade or business, $\$ 1374$ (d) (1) invokes the limitations of $\$ 270$.

45 See second paragraph of note 44 supra.

46 Only the amount by which the allowable portion of the net operating loss exceeds the shareholder's income may be used as his own net operating loss. For limitations on the amount of the net operating loss whicl is allowable, see note 44 silpra and accompanying text.

47 Thus the amount which may be carried over to the shareholders as capital gains may not exceed the taxable income of the electing corporation for the current year. This is because taxable incorne cannot exceed the current earnings and profits. See note 29 supra. Accordingly, current ordinary losses of the electing corporation will reduce the amount of capital gains which can be carried over to the shareholders. In this connection it should be noted that, although the use by the electing corporation of a net operating loss carryover is specifically prohibited, there is nothing in the statutes which would bar the use by the corporation of a capital loss carryover during the election period. Therefore, capital loss carryovers of an electing corporation will reduce the amount of current capital gaims which may be allocated to the shareholders of the electing corporation. Conversely, neither a net capital loss for a current year nor a capital loss carryover of the electing corporation can be attributed to the shareholders, and therefore neither can be used by them to offset their own capital gains. There is no apparent reason why the draftsmen of subchapter $S$ did not treat capital losses of an electing corporation in the same manner as net operating losses, i.e., suspend the use by the corporation of a pre-election capital loss carryover until a non-election year, and pass on to the shareholders a net capital loss which occurs in an election year. See note 23 and text preceding note 40 supra. 
capital gain to the extent of the shareholder's pro rata share of the excess of the electing corporation's net long-term capital gain over its net short-term capital loss for the taxable year in question. The shareholder's pro rata share is determined in the same manner as is his pro rata share of constructive dividends. This is the only part of subchapter $\mathrm{S}$ which provides that constructive dividends which are attributed to the shareholders have the same tax character in their hands as they had in the hands of the electing corporation. ${ }^{48}$ Items of tax-exempt income-such as municipal bond interest or life insurance proceeds-which are tax free on receipt by the corporation do not carry over that status to the shareholders of an electing corporation and are therefore taxable to them to the extent imcluded in constructive dividends..$^{49} \mathrm{~A}$ partnership, of course, can transmit these items to its members tax free. .0

It is obvious that this section may open up an avenue for circumventing the disadvantages of the collapsible corporation rules of section 341. The collapsible corporation rules are intended to prevent long-term capital gains treatment by shareholders on income-earning assets, either by distribution of the assets to them by the corporation in complete or partial liquidation before the corporation has realized the income from these assets and paid tax thereon, or by sale by the shareholder of his stock in the corporation under the same circumstances. The shareholder will normally realize ordinary income from such a liquidation or sale by reason of section 341. Under section 1375 (a), however, if the corporation otherwise qualified as an electing corporation, it could sell the income producing assets, realizing section 1231 gain which would be mcluded in its undistributed taxable income as long-term capital gain-assuming the requisite holding period and no offsetting section 1231 losses-and be taxed to the shareholders as long-term capital gam. This amount reported by the shareholders would in addition increase the basis of their stock, and thus decrease or eliminate entirely any gain either from the later sale of the stock or from liquidation of the corporation by distribution to the shareholders of the proceeds of the sale of its assets. ${ }^{51}$ Whether this loophole to section 341 will remain in the code for long remains to be seen.

Section 1375(b) provides that the amount includible in the gross income of shareholders as dividends from an electing corporation during any taxable year of the corporation-including both constructive and actual dividends-shall not be considered a dividend for purposes of the dividend credit, exclusion, and retirement income credit provisions of the code, ${ }^{52}$ but only to the extent that such dividends are out of current earnings and profits. In other words, dividends which are allocable to accumulated earnings and profits are treated as ordinary dividends. ${ }^{53}$

48 Note that capital gains under $\$ 1231$, when allocated to the shareholders, are treated as any other capital gains and are not subject to being offset by any $\$ 1231$ losses the shareholder may have incurred during the year in question. This is not true of $\$ 1231$ gains of a partnership which are allocated to its members ( $\$ 702(b))$.

40 These items of income which are tax-exempt at the corporate level are not excluded from constructive dividends due to the provisions of $\$ 1377$ (b). See note 29 supra and text at note 62 infra.

${ }^{50}$ Section $702(\mathrm{~b})$.

61 For further discussion of this point, see particularly Axelrad, Recent Developments in Collapsible Corporations, 36 Taxes 893, 906 (1958).

82 Sections 34,116 and 37 , respectively.

53 Of course, a distribution wbich is allocable neither to current nor to accumulated earnings and profits is not a dividend at all, but rather a return of capital. For discussion of the problems involved in allocating distributions between current and accumulated earnings and profits, see text between notes 28-39 supra, particularly at note 38 . 
Section 1375 (c) provides that any dividend received by a shareholder from an electing corporation may be apportioned or allocated by the Commissioner between or among shareholders of such corporation who are members of such shareholder's family ${ }^{54}$ if he determines that such apportionment or allocation is necessary in order to reflect the value of services rendered to the corporation by such shareholders. ${ }^{55}$

Section 1375(d), which prescribes the treatment of distributions of constructive divideuds which have been retained by the electing corporation, is one of the most interesting provisions of subchapter S. Such distributions may be made in accordance with regulations to be prescribed by the Service. The general rule is that constructive dividends increase the basis of the stock of the shareholder to whom they are attributed under section 1373 and that subsequent distributions of retained constructive dividends are treated as returns of capital and merely reduce the basis of the stock of the recipient shareholder. ${ }^{56}$ This section, however, imposes a penalty on shareholders of a corporation which was once an electing corporation but whose election has been, or was at one time, revoked or terminated. Any break in the election means that no distribution made after the break, even if made in a year when a new election is in effect, can be earmarked as being made from retained constructive dividends. Therefore any such distribution will be a dividend, rather than a return of capital, to the extent that the corporation has current or accumu lated earnings and profits. ${ }^{57}$ It should also be noted that even with respect to a corporation with no break in election, the right to earmark distributions as being made from retained constructive dividends is personal to the shareholder to whom such retained constructive dividends were originally attributed. Therefore, the sale of stock will cause the loss of the right to earmark any subsequent distributions with respect to that stock as being made from retained constructive dividends which were accumulated prior to the sale. ${ }^{58}$

This section results in a penalty to the shareholders of a corporation which terminates or revokes its election and which has retained part of the constructive dividends for an election year. The theory of the penalty apparently is to tax the income twice, just as it would have been if an election were not in effect, but taxing it to the shareholder both times rather than to the corporation once and to the shareholder the other time. ${ }^{59}$ It should be noted, however, that the effect of this penalty can be avoided if an electing corporation clistributes all retained constructive dividends before its election is terminated or revoked. Such a plan of current distribution of constructive dividends would, in addition, be desirable in cases where the shareholders needed the cash with which to pay their income taxes, such taxes being increased because of the constructive dividends. ${ }^{80}$

54 Members of the family are determined under $\$ 704$ (e) (3).

55 Compare the treatment of family partnerships under $\S 704(\mathrm{e})(2)$.

56 Sections 1376 (a) and 1375 (d), respectively.

57 See text at note 61 infra.

58 Apparently a repurchase of the shares by the stockholder to whom the constructive dividends were attributed will reinstate the right to earmark subsequent distributions with respect to that stock as being made from those retained constructive dividends.

69 Depending on the tax bracket of the individual shareholer, this may be either more or less advantageous than the result which would obtain if the normal corporate form were employed and all earnings and profits were distributed.

60 The apparent harshness of this provision is also alleviated by the fact that constructive dividends increase the shareholders' basis for their stock and thus result in a tax advantage upon a subsequent disposition of such stock $(\S 1376(a))$. A distribution by the corporation which is not allowed to be allocated to retained constructive dividends would not reduce this basis (\$1375(d)(1)) unless the corporation had no current or accumulated earnings and profits. See also notes 61 and 70 infra and accompanyihg texts. 


\section{Section 1376: Adjustments to Basis}

Section 1376 provides for adjustments to the basis of stock or imdebtedness owing a shareholder by the corporation. The basis of stock is increased for any constructive dividends as of the time they are required to be included in the shareholder's return, but only to the extent actually so included. The basis of a shareholder's stock is decreased, but not below zero, by an amount equal to his portion of the corporation's net operating loss which is attributable to such stock under section $1374(c)$ and is similarly reduced by any distributions of retained constructive dividends which are treated as a return of capital under section 1375 (d). The section also provides for a reduction in the basis, but not below zero, of any indebtedness of an electing corporation to a shareholder by an amount equal to the excess of his portion of net operating loss over the basis of his stock.

\section{Section 1377: Adjustments to Earnings and Profits}

Section 1377 provides rules for adjustments to earnings and profits of electing corporations. Section 1377 (a) provides that the accumulated earnings and profits of an electing corporation as of the close of its taxable year shall be reduced to the extent that its undistributed taxable income for such year is allocated to its shareholders as constructive dividends. Since the accumulated earnings and profits are thus reduced by the amount of constructive dividends for the taxable year, this provision seems to reduce the effect of the penalty provision of section 1375(d) in that a distribution cannot be a taxable dividend if it is not from earnings and profits, either accumulated or current. If a distribution is not allocable to earnings and profits, it is a return of capital. However, the penalty provision of section 1375 (d) would still have the effect of requiring a distribution to be allocated to accumulated earnings and profits if there are any, rather than to capital, so that its effect will be circumvented only in the case of a corporation with no accumulated earnings and profits. ${ }^{61}$

In order to equate current earnings and profits with taxable income for the purpose of determining constructive dividends under section 1373 (b), section 1377 (b) provides that the current earnings and profits-not accumulated earnings and profits-shall not be reduced by any amount which is not allowable as a deduction in computing taxable incoine under section 1373 (d). Thus, a net capital loss for the current year or premium payments on life insurance policies owned by the corporation will not reduce current earnings and profits and will therefore not reduce constructive dividends. ${ }^{62}$

Section 1377 (c) provides that the earnings and profits, both current and accumulated, of an electing corporation shall not be affected by any item of income or deduction taken into account in deternining a net operating loss as computed under section $1374(\mathrm{c})$. The new legislation also provides for the amendment of section 172 to provide that in computing the amount of a corporation's net operating loss there shall be disregarded the net operating loss of such corporation for any taxable year for which it was an electing corporation. The reason for these provisions is that the net operating loss of an electing corporation is allocated directly to the shareholders, so that reduction of earnings and profits or allowance in computing a later net operating loss would result in a double tax advantage from this source. ${ }^{63}$

61 See discussion of the "penalty" provision in notes 56-60 supra and accompanying texts.

62 See S. Rep. No. 1983, 85th Cong., 2d Sess. 225 (1958). See also note 29 and text at note 49 supra. Cf. notes 23-24 supra and accompanying text.

63 See note 23 supra. 


\title{
Section 6037: Information Returns
}

Section 6037 was added to the code to provicle for the filing of an information return by an electing small business corporation similar to that required of a partnership. The return must show

\begin{abstract}
the items of its gross income and the deductions allowable by subtitle $A$, the names and addresses of all persons owning stock in the corporation at any time during the taxable year, the number of shares of stock owned by each shareholder at all times during the taxable year, the amount of money and other property distributed by the corporation during the taxable year to each shareholder, the date of each such distribution, and such other information, for the purpose of carrying out the provisions of subchapter S of chapter 1 , as the Secretary or his delegate may by forms and regulations prescribe. 64
\end{abstract}

The regulations provide that the information return is to be filed with the district director with whom the income tax return of the corporation would have been filed if it were not an electing corporation and that it is to be filed within three months after the close of the corporation's taxable year. ${ }^{05}$

\section{ConcLusion}

The most significant advantages of status as an electing small business corporation are the avoidance of the double tax, the treatment of capital gains-including the collapsible corporation gimmick-and the attribution of the electing corporation's net operating loss to the shareholders, to whom it may be more useful. In addition, a partnership which incorporates ${ }^{6 B}$ and becomes an electing corporation will qualify thereby for executive compensation plans and other fringe benefits. ${ }^{07}$ However, these factors may be of doubtful utility, or even a disadvantage, in the case of a corporation which does not anticipate losses or capital gains or which has a large loss carryover, and in which the double tax: is not a disadvantage either because amounts which otherwise might be dividends are withdrawn as salaries or because the shareholders wish to reinvest the earnings and their personal income tax brackets are sufficiently high so that it is less burdensome to have the earnings taxed to the corporation with capital gain treatment when the shares ultimately are sold or the corporation hiquidated.

In all, however, the safest thing to say about subchapter $S$ is that it should be employed with extreme caution. The foregoing discussion has pointed out some of the possible dangers-such as loss of retained constructive dividends if there is a break in the election, elimination of a loss carryover which would be available in the absence of an election, and loss of tax-exempt status of certain items of in. come. $^{68}$ In addition, it should be reiterated that a corporation which wishes to remain an electing corporation must place extreme restrictions on the transfer of its shares so that a disqualifying transfer will not be made. The necessity for these

\section{Section 6037.}

o5 Temp. Treas. Reg. § 18.1-1(e), 23 Fed. Reg. 7485 (1958).

68 See note 13 supra and references contained therein.

07 An electing small business corporation apparently is a corporation for all tax purposes except for the imposition of federal income tax at the corporate level. In this connection, a corporation or partnership contemplating going on the election should consider the tax consequences at the state level. There is no reason to suppose that an election under subchapter $\mathbf{S}$ would alter the corporation's status as a taxpaying entity at the state level. Therefore the question is presented whether the shareholders must include in their gross income for state income tax purposes constructive dividends which have not actually been received.

08 This list is by no means exhaustive. 
restrictions on transfer, the impediment to new financing presented by the limitation to one class of stock, the necessity of distributing constructive dividends currently in order to avoid the loss of the right to earmark subsequent distributions as being a return of capital, and the fact that a sale of stock eliminates the right to so earmark distributions will make any closely held corporation which contemplates expansion extremely dubious of becoming an electing corporation. ${ }^{69}$

These disadvantages may mean that the election will be utilized primarily by a corporation or partnership as a one-year method of attributing to shareholders either a large nonrecurring loss which may be more useful to them than to the corporation or a large nonrecurring capital gain which will retain that character in the hands of the shareholders. ${ }^{70}$

Richard A. Wilson

69 See note 12 sucpra and accompanying text for the possibility of debt financing.

70 The disadvantages of an election which have been discussed in this comment would not be applicable to a corporation which uses the election solely for this purpose. 